\title{
PELATIHAN MAHASISWA DI UNIT PELAYANAN BIMBINGAN DAN KONSELING UNINDRA: PEMAHAMAN SELF CONCEPT REMAJA MELALUI DOODLE ART
}

\author{
STUDENT TRAINING IN UNINDRA GUIDANCE AND COUNSELING \\ SERVICE UNIT: UNDERSTANDING SERVICE CONCEPT ADOLESCENTS \\ THROUGH DOODLE ART
}

\author{
Sisca Folastri ${ }^{{ }^{*}}$, Solihatun Solihatun ${ }^{2}$ \\ ${ }^{1,2}$ Universitas Indraprasta PGRI \\ ${ }^{1}$ Email: siscafolastri@gmail.com
}

\begin{abstract}
Abstrak: Konsep diri merupakan sifat unik yang pada manusia, sehingga dapat digunakan untuk membedakan manusia dari makhluk hidup lainnya. Sesuai dengan kondisi yang ditemui oleh tim, masih ditemui individu yang tidak mampu mengendalikan dirinya karena kekurangpahaman individu tersebut terhadap dirinya (self concept), tidak mengetahui kemampuan yang dimiliki. Oleh karena itu, kegiatan pengabdian dilakukan untuk memahami bagaimana konsep diri melalui Doodle Art. Kegatan pengabdian masyarakat ini dilakukan selama dua hari pada mahasiswa asisten UPBK Unindra. Pelaksanaan kegiatan dilakukan dengan metode ceramah, tanya jawab, diskusi dan praktik pemahaman konsep diri melalui Doodle Art. Hasil evaluasi kegiatan yang sudah dilakukan terungkap bahwa kegiatan Doodle Art berhasil dan memberikan kebermanfaatan kepada individu dalam mengarahkan konsep diri yang positif. Hal ini terihat dari antusias dan keikutsertaan peserta selama kegiatan Doodle Art.
\end{abstract}

Kata Kunci: Pemahaman, Self concept, Doodle art

\begin{abstract}
The self concept is a unique trait in humans, so that it can be used to distinguish humans from other living things. In accordance with the conditions encountered by the team, still found individuals who are unable to control themselves because of the individual's lack of understanding of him (self concept), do not know the capabilities possessed. Therefore, the service is carried out to understand how selfconcept through Doodle Art. The activity of community service was carried out for two days by the assistant students of UPBK Unindra. The activities carried out by lecturing, question and answer, discussion and practice of self-concept understanding through Doodle Art. The results of the evaluation of activities that have been carried out revealed that Doodle Art activities are successful and provide benefits to individuals in directing positive self-concepts. This can be seen from the enthusiasm and participation of participants during the Doodle Art activities
\end{abstract}

Keywords: Understanding, Self concept, Doodle art 


\section{INTEGRITAS : Jurnal Pengabdian}

Vol 4, No 1, Juli 2020

ISSN 2580-7978 (cetak) ISSN 2615-0794 (online)

\section{PENDAHULUAN}

Konsep diri (self concept) merupakan suatu bagian yang penting dalam setiap pembicaraan tentang kepribadian manusia (Silaban, 2018). Konsep diri merupakan sifat yang unik pada manusia, sehingga dapat digunakan untuk membedakan manusia dari makhluk hidup lainnya. (Handini, 2010). Lebih lanjut Konsep diri adalah konseptualisasi individu terhadap dirinya sendiri. Konsep diri secara langsung mempengaruhi harga diri dan perasaan seseorang tentang dirinya sendiri (Potter \& Perry, 2010).

Konsep diri yang positif dapat membantu seseorang untuk meningkatkan kepercayaan terhadap dirinya sehingga dapat memotivasi seseorang untuk dapat menjadi lebih baik lagi. Prestasi akademik individu mempengaruhi konsep diri individu (Pambudi \& Wijayanti, 2012). Pada tahap selanjutnya konsep diri dan prestasi akademik saling mempengaruhi baik secara positif maupun negatif. Konsep diri terbentuk dari proses belajar dari lingkungan sekitarnya baik lingkungan keluarga, teman sebaya, sekolah dan masyarakat (Saraswatia, Zulpahiyana, \& Arifah, 2015).

Tinggi rendahnya atau positif negatifnya konsep diri siswa adalah hasil dari belajar. Apabila siswa memiliki konsep diri yang tinggi ia mampu melakukan tugas-tugas belajarnya dengan baik serta memiliki pengharapan terhadap dirinya sendiri, memiliki tujuan hidup kedepan. Konsep diri remaja kerap kali berubah sesuai dengan kondisi dan situasi yang dihadapi, apalagi siswa yang menghadapi masa transisi, pada kondisi menghadapi proses penyesuaian diri dari masa kanakkanak ke masa remaja yang penuh dengan gejolak emosi. Sedangkan menurut (Burns, 1993) "konsep diri sebagai pandangan, penilaian, dan perasaan individu mengenai dirinya yang timbul sebagai hasil dari suatu interaksi sosial”.

Selanjutnya, jika melihat dari hasil penelitian oleh (Situmorang \& Latifah, 2014) menyebutkan bahwa seorang remaja dengan variabel konsep diri menunjukan bahwa lebih dari setengah anak $(69,3 \%)$ memiliki konsep diri berada pada kategori rendah. Penelitian lain oleh Amalia (2015) dalam (Atuti, 2017) juga menyatakan bahwa konsep diri memiliki konstribusi yang positif terhadap 


\section{INTEGRITAS : Jurnal Pengabdian}

Vol 4, No 1, Juli 2020

ISSN 2580-7978 (cetak) ISSN 2615-0794 (online)

mengendalikan diri sehinga semakin positif konsep diri maka semakin tinggi pengendalian diri remaja tersebut, sebaliknya semakin negatif konsep diri maka semakin rendah pengendalian diri remaja tersebut, sehingga hal ini mencerminkan bahwa memiliki konsep diri menjadi salah satu cara untuk dapat meningkatan daya kendali diri individu. Beberapa hasil penelitian di atas senada dengan dengan kondisi yang ditemui oleh tim abdimas yang telah dilakukan sebelumnya kepada mahasiswa UPBK UNINDRA dengan memberikan pelatihan kendali diri melalui media ekspresi. Dari hasil pelatihan tersebut tim mengamati masih ditemui mahasiswa UPBK yang tidak mampu mengendalikan dirinya karena kekurangpahaman dirinya tersebut terhadap dirinya (konsep diri), tidak mengetahui kemampuan yang dimiliki serta tidak mampu mengenali kelebihan dan kekurangan yang ia miliki.

Hal ini terjadi mengingat mereka adalah remaja yang belum memahami tentang konsep dirinya sendiri. Berdasarkan kenyataan dilapangan terdapat individu baik remaja awal sampai remaja akhir yang kurang bahkan tidak memahami konsep diri, kelebihan dan kelemahan yang ia miliki. Hal tersebut terjadi karena remaja dipengaruhi oleh pencarian jati diri, serta ingin mencoba hal-hal yang baru (Tridhonanto, 2010).

Mahasiswa yang memiliki tugas sebagai asisten UPBK Unindra memiliki tugas sebagai pendamping tutor sebaya dalam membantu rekan-rekannya yang sedang merasakan permasalahan dengan kondisi kurangnya wawasan, pengetahuan, keterampilan, nilai dan sikap (WPKNS). Selanjutnya, mahasiswa asisten UPBK nantinya sebagai calon konselor semestinya memiliki kecakapan dalam membantu rekan-rekannya sesama mahasiswa untuk dapat menjadi pribadi yang mandiri dan positif dengan menjalankan kehidupannya secara optimal, artinya dengan kata lain mahasiswa UPBK UNINDRA semestinya memiliki konsep diri yang positif.

Menyikapi dari beberapa permasalahan diatas terungkap bahwa mahasiswa sebagai asisten UPBK UNINDRA memiliki tugas pokok untuk mengemban 


\section{INTEGRITAS : Jurnal Pengabdian}

Vol 4, No 1, Juli 2020

ISSN 2580-7978 (cetak) ISSN 2615-0794 (online)

fungsinya dan sebagai calon konselor yang akan dibutuhkan di sekolah, di luar sekolah serta masyarakat luas, namun karena mengingat mereka masih remaja, maka perlu pelatihan lain untuk mengembangkan konsep dirinya salah satu nya adalah dengan Doodle Art.

Doodling merupakan teknik menggambar atau mencoret secara spontan, dalam menggambarkan bentuk yang ada oleh pikiran kita (Olivia, 2013). Pada dasarnya menggambar doodle menghasilkan bentuk-bentuk yang imaginatif dan beragam. Doodle Art dalam bahasa indonesia berarti mencoret. Doodle art juga bisa di sebut freehand art dan bersifat Abstract. Doodle Art ada yang berwarna dan ada yang tidak. walaupun tidak berwarna dan tidak memiliki bentuk yang benar, namun terlihat menarik. Doodle art sangat simple, dengan hanya menggunakan pulpen lalu kita mencoret-coret, itu semua termausk doodle art. ciri utama doodle art adalah spontan.

Menggambar secara spontan dengan cara mencoret dan terlihat abstrak dengan mengembangkan sebuah garis acak menjadi bentuk yang bermakna maupun tidak bermakna sama sekali, bahkan terkadang karya yang dihasilkan tidak memiliki bentuk yang benar namun terlihat unik dan menarik. Seperti kita ketahui tujuan dari kegiatan menggambar adalah untuk melatih proses mental, mengingat, berimajinasi, mengungkapkan emosi, dan meningkatkan kemampuan berpikir. Sebuah karya doodle biasanya melukiskan perasaan si pembuatnya, bisa terlihat dari goresan-goresan yang dihasilkan, kadang keluar tanpa disadari oleh pikiran kita (Nida, 2018). Doodle art kadang mampu menenangkan hati si pembuatnya. Semakin di buat dengan sepenuh jiwa dan perasaan, karya yang dihasilkan semakin menarik, unik dan bermakna dalam, dan itu membuat karya doodle tidak sekedar jadi hobi corat-coret, tapi juga mempunyai kedalaman makna dan gaya. (Puspita Sari \& Fitri, 2018).

Berdasarkan dari pemikiran tersebut, maka dari itu untuk untuk meningkatkan pemahaman konsep diri yang positif diperlukan Doodle Art. Kegiatan pelatihan ini merupakan kegiatan yang pertama kali dilakukan oleh 


\section{INTEGRITAS : Jurnal Pengabdian}

mahasiswa UPBK UNINDRA dalam rangka meningkatkan pemahaman konsep diri yang positif.

\section{METODE}

Pelaksanaan kegiatan pelatihan ini menggunakan metode ceramah (Permata \& Tarigan, 2009), tanya jawab (Gagaramusu, 2014), diskusi (Dewi, 2014) dan praktik doodle art dalam memahami konsep diri mahasiswa. Untuk mengawali kegiatan menggunakan metode ceramah yaitu pemateri menjelaskan tujuan kegiatan pelatihan dilaksanakan, menjelaskan peralatan yang akan digunakan dalam pelatihan doodle art yang perlu diketahui oleh peserta latihan, dan langkahlangkah melaksanakan kegiatan doodle art. Metode tanya jawab yaitu tentang makna gambar terkait konsep diri yang sudah dibuat oleh peserta latihan. Selanjutnya pada metode diskusi digunakan untuk memberikan kesempatan kepada peserta mengungkapkan pengalaman, pendapat, permasalahan, dan usaha yang selama ini dilakukan terkait dengan materi pelatihan sehingga semua permasalahan dan kendala yang dihadapi selama ini dan saat pelatihan dapat terentaskan. Kemudian metode praktik dilakukan untuk memantapkan pemahaman, penguasaan, dan keterampilan dalam mengetahui potret diri mereka melalui gambar.

\section{HASIL DAN PEMBAHASAN}

Hasil dan pembahasan kegiatan abdimas yang dilakukan oleh tim mengenai PKM Kelompok Remaja Mahasiswa UPBK UNINDRA: Pemahaman Self Concept Remaja Melalui Doodle Art. Dalam pelaksanaannya, kegiatan abdimas ini berlangsung selama 2 hari. Adapun kegiatan-kegiatan yang telah dilakukan adalah sebagai berikut:

Hari 1:

1. Sosialisasi akan diadakannya kegiatan pengabdian kepada mahasiswa di UPBK UNINDRA 


\section{INTEGRITAS : Jurnal Pengabdian}

2. Memahami karakteristik mitra untuk dilaksanakan kegiatan pengabdian kepada masyarakat

3. Identifikasi permasalahan yang sedang dirasakan oleh mitra melalui wawancara dan observasi.

4. Identifikasi alat-alat yang dibutuhkan pada saat kegiatan pengabdian kepada masyarakat untuk mitra dilaksanakan.

5. Identifikasi materi yang akan diberikan kepada mitra.

6. Mempersiapkan kegiatan Abdimas kepada mitra mengenai PKM Kelompok Remaja UPBK UNINDRA: Pemahaman Self Concept Remaja Melalui Doodle Art

Hari ke 2:

1. Pemaparan materi kepada mitra mengenai Pemahaman Self Concept Remaja Melalui Doodle Art, oleh tim kegiatan PKM.

2. Pelaksanaan kegiatan pengabdian kepada masyarakat, yaitu Pemahaman Self Concept Remaja Melalui Doodle Art mahasiswa UPBK UNINDRA dibantu oleh tim PKM.

3. Laiseg, laijapen, dan laijapang serta Evaluasi kegiatan pengabdian kepada masyarakat yang telah dilakukan.

4. Berdasarkan hasil wawancara dengan Mahasiswa UPBK UNINDRA selaku mitra meyakini bahwa melalui PKM Kelompok Remaja UPBK UNINDRA: Pemahaman Self Concept Remaja Melalui Doodle Art, maka (WPKNS) wawasan, pengetahuan, keterampilan, nilai, dan sikap mereka sebagai tutor sebaya bertambah dan lebih positif terutama dalam kebermanfaatan sebagai calon konselor kepada sesama rekan mahasiswa yang berlandaskan kepada pemberian teknik-teknik dalam konseling.

Kegiatan Doodle Art bagi mahasiswa UPBK dirasakan kegiatan yang luar biasa dilakukan untuk menambah keterampilan mereka dalam melaksanakan konseling nantinya.

Mahasiswa dengan antusias dan semangat mengikuti kegiatan penggunaan Doodle Art sebagai media untuk pemahaman konsep diri positif. Kegiatan ini 


\section{INTEGRITAS : Jurnal Pengabdian}

Vol 4, No 1, Juli 2020

ISSN 2580 - 7978 (cetak) ISSN 2615 - 0794 (online)

melatih mahasiswa UPBK untuk mengembangkan konsep dirinya sehingga lebih positif, mahasiswa lebih mampu mengendalikan dirinya, dan mahasiswa lebih mengetahui kelebihan dan kekurangan nya masing-masing, dari mahasiswa yang sulit mengungkapkan apa yang ia rasakan, dengan Doddle Art mahasiswa bisa menjelaskan dalam kelompok arti dari makna yang ada dalam gambarnya. Ketika individu menjelaskan gambar yang dibuat tanpa disadari individu hanyut dengan suasana dan mengekspresikan apa yang selama ini terpendam yang membuat diri menjadi tidak semangat menjalani kehidupan. Berikut gambar pelatihan yang telah dilakukan oleh tim Abdimas.

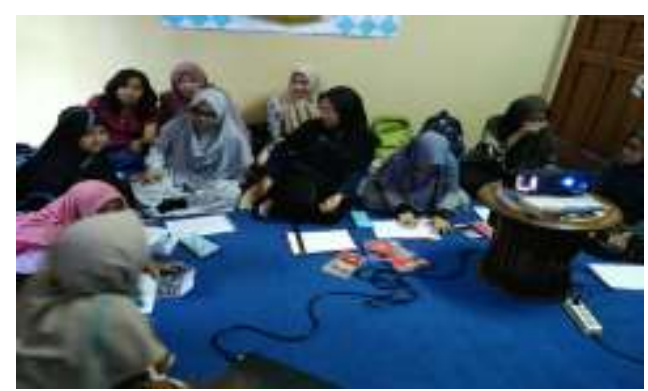

Gambar 1

Mahasiswa UPBK sedang melakukan kegiatan Doodle Art

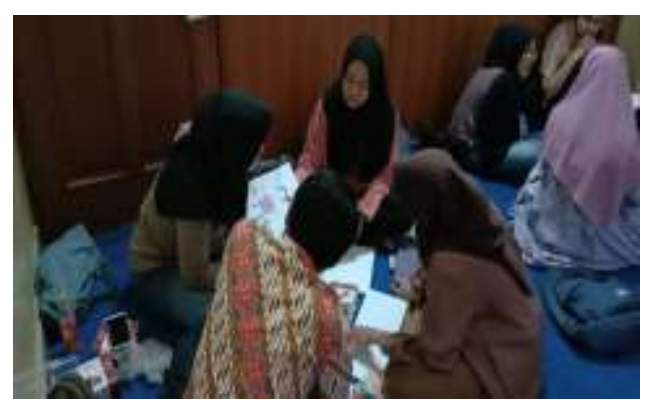

Gambar 2

Mahasiswa dibagi dalam beberapa kelompok melakukan kegiatan doodle art

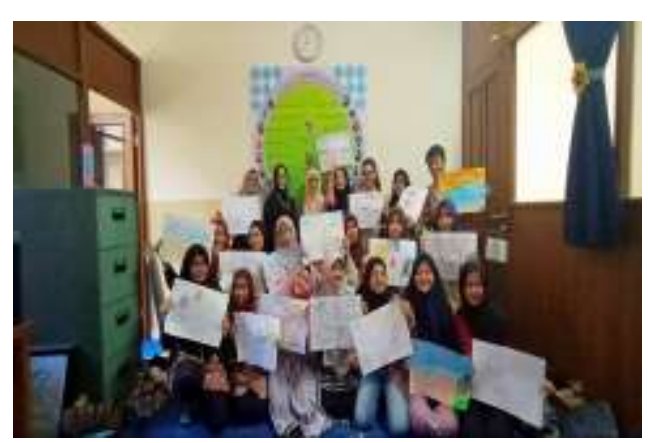




\section{Gambar 3 \\ Tim abdimas dan Mahasiswa UPBK}

Adapun implikasi dari temuan adalah sebagai berikut:

1. Bertambahnya (WPKNS) wawasan, pengetahuan, keterampilan, nilai, dan sikap yang dimiliki Mahasiswa UPBK UNINDRA sehingga memiliki konsep diri yang positif

2. Mahasiswa UPBK Unindra memiliki Keterampilan sehingga ketika melakukan pendampingan tutor sebaya dalam membantu rekan-rekannya yang sedang merasakan permasalahan dengan kondisi kurangnya WPKNS sehingga merubah perlilaku yang KET. dalam rangka mengembangkan pemahaman konsep diri yang positif melalui Doddle Art.

3. Menambah wawasan, pengetahuan, keterampilan, nilai dan sikap (WPKNS) tentang teknik-teknik konseling yang dapat digunakan dalam rangka mengembangkan pemahaman konsep diri yang positif melalui Doddle Art. Sehingga dikemudian hari mahasiswa UPBK menjadi calon guru BK ataupun konselor yang siap, mantap dan sigap dimana-mana.

Senada dengan penelitian sebelumnya oleh (Ranny et al., 2017) bahwa konsep diri dapat berkembang ke arah yang lebih positif dengan layanan BK melalui guru BK. Dalam hal ini tim abdimas memberikan layanan BK dengan teknik Doddle Art.

\section{KESIMPULAN}

Kegiatan pelatihan Doodle Art memberikan kebermanfaatan yang luar biasa yaitu bertambahnya wawasan, pengetahuan, keterampilan, nilai, dan sikap (WPKNS) yang dimiliki oleh Mahasiswa UPBK UNINDRA yaitu memiliki keterampilan sehingga ketika melakukan pendampingan tutor sebaya dengan rekan-rekannya yang sedang merasakan kehidupan efektif sehari-harinya 


\section{INTEGRITAS : Jurnal Pengabdian}

Vol 4, No 1, Juli 2020

ISSN $2580-7978$ (cetak) ISSN 2615 - 0794 (online)

terganggu dan kurangnya kondisi WPKNS, merubah perilaku yang kehidupan efektif sehari-harinya terganggu menjadi kehidupan sehari-harinya efektif dalam rangka mengembangkan pemahaman konsep diri yang positif. Menambah pengetahuan tentang teknik-teknik konseling yang bisa digunakan dalam pengembangan fungsinya sebagai calon guru BK ataupun konselor dikemudian hari.

\section{UCAPAN TERIMA KASIH}

Terimakasih kepada mahasiswa asisten UPBK Unindra, ketua LP2M Universitas Indraprasta PGRI, tim pelaksana, dan semua pihak yang sudah terlibat dalam pelaksanaan kegiatan pengabdian kepada masyarakat. .

\section{DAFTAR PUSTAKA}

Atuti, F. (2017). Hubungan antara Konsep Diri dengan Resiliensi pada Mahasiswa Tahun Pertama Program Kelas Karyawan. Yogyakarta: Universitas Mercu Buana Yogyakarta.

Burns, R. B. (1993). Konsep Diri: Teori, pengukuran, perkembangan dan perilaku. Jakarta: Arcan.

Dewi, N. (2014). Metode Biblioterapi dan Diskusi Dilema Moral untuk Pengembangan Karakter Tanggungjawab, 41(1), 47-59.

Gagaramusu, Y. (2014). Penerapan Metode Tanya Jawab untuk Meningkatkan Hasil Belajar Siswa Pada Pokok Bahasan Sumber Daya Alam di Kelas IV SDN Fatufia Kecamatan Bahodopi, 1(1), 214-227.

Handini, F. (2010). Hubungan konsep diri dengan kecenderungan berperilaku bullying siswa SMAN 70 Jakarta.

Nida, S. (2018). Eksistensi Doodle Dalam Komunitas Doodle Art Indonesia Regional Kudus Sebagai Media Berekspresi Anak Muda (Studi Deskriptif Kualitatif Eksistensi Komunitas Doodle Art Kudus Pada Anak Muda di Kabupaten Kudus). Fakultas Bahasa dan Ilmu Komunikasi UNISSULA.

Olivia, F. (2013). Gembira bermain corat coret. Elex Media Komputindo.

Pambudi, P. S., \& Wijayanti, D. Y. (2012). Hubungan konsep diri dengan prestasi akademik mahasiswa keperawatan. Jurnal Keperawatan Soedirman, 7(2), 93-99. 
INTEGRITAS : Jurnal Pengabdian

Vol 4, No 1, Juli 2020

ISSN 2580 - 7978 (cetak) ISSN 2615 - 0794 (online)

Permata, A., \& Tarigan, S. (2009). Harapan Mekar Medan, 250-258.

Potter, P., \& Perry, A. G. (2010). Fundamental Of Nursing: Consep, Proses and Practice. Edisi I, 3.

PUSPITA SARI, Z., \& Fitri, R. (2018). Pengaruh Kegiatan Doodle Art melalui Metode Demonstrasi terhadap Kemampuan Motorik Halus Anak Kelompok A TK Aisyiyah 16 Wotan Panceng Gresik. PAUD Teratai, 7(3).

Ranny, R., AM, R. A., Rianti, E., Amelia, S. H., Novita, M. N. N., \& Lestarina, E. (2017). Konsep Diri Remaja dan Peranan Konseling. JPGI (Jurnal Penelitian Guru Indonesia), 2(2), 40-47.

Saraswatia, G. K., Zulpahiyana, Z., \& Arifah, S. (2015). Faktor-faktor yang mempengaruhi konsep diri remaja di SMPN 13 Yogyakarta. Jurnal Ners Dan Kebidanan Indonesia, 3(1), 33-38.

Silaban, T. L. (2018). PENGaruh Layanan Penguasaan Konten dengan Teknik Modelling untuk Meminimalisir Konsep Diri Negatif Siswa Smp Nasrani 5 Medan Kelas VII Tahun Ajaran 2017/2018. Unimed.

Situmorang, Z. R. D., \& Latifah, M. (2014). Pengaruh dukungan sosial, konsep diri, dan strategi pengaturan diri dalam belajar terhadap prestasi akademik. Jurnal Ilmu Keluarga \& Konsumen, 7(3), 154-163.

Tridhonanto, A. (2010). Meraih Sukses Dengan Kecerdasa Emosional. Elex Media Komputindo. 